\title{
Temporal and Spatial Coexistence of Archaeal and Bacterial amo $A$ Genes and Gene Transcripts in Lake Lucerne
}

\author{
Elisabeth W. Vissers, ${ }^{1}$ Flavio S. Anselmetti, ${ }^{2,3}$ Paul L. E. Bodelier, ${ }^{1}$ Gerard Muyzer, ${ }^{1,4}$ \\ Christa Schleper, ${ }^{5}$ Maria Tourna, ${ }^{6}$ and Hendrikus J. Laanbroek ${ }^{1,7}$ \\ ${ }^{1}$ Department of Microbial Ecology, Netherlands Institute of Ecology (NIOO-KNAW), Droevendaalsesteeg 10, \\ 6708 PB Wageningen, The Netherlands \\ ${ }^{2}$ Swiss Federal Institute of Aquatic Science and Technology (Eawag), Überlandstrasse 133, 8600 Dübendorf, Switzerland \\ ${ }^{3}$ Institute of Geological Sciences and Oeschger Centre for Climate Change Research, University of Bern, Zähringerstrasse 25, \\ 3012 Bern, Switzerland \\ ${ }^{4}$ Department of Aquatic Microbiology, University of Amsterdam, Science Park 904, 1098 XH Amsterdam, The Netherlands \\ ${ }^{5}$ Department of Genetics in Ecology, University of Vienna, Althanstrasse 14, 1090 Vienna, Austria \\ ${ }^{6}$ AgResearch Ltd., Ruakura Centre, East Street Private Bag 3115, Hamilton 3240, New Zealand \\ ${ }^{7}$ Institute of Environmental Biology, Utrecht University, Padualaan 8, 3584 CH Utrecht, The Netherlands
}

Correspondence should be addressed to Elisabeth W. Vissers; liesbeth.vissers@gmail.com

Received 12 November 2012; Accepted 15 January 2013

Academic Editor: Hans-Peter Klenk

Copyright (C) 2013 Elisabeth W. Vissers et al. This is an open access article distributed under the Creative Commons Attribution License, which permits unrestricted use, distribution, and reproduction in any medium, provided the original work is properly cited.

Despite their crucial role in the nitrogen cycle, freshwater ecosystems are relatively rarely studied for active ammonia oxidizers (AO). This study of Lake Lucerne determined the abundance of both amoA genes and gene transcripts of ammonia-oxidizing archaea $(\mathrm{AOA})$ and bacteria $(\mathrm{AOB})$ over a period of 16 months, shedding more light on the role of both $\mathrm{AO}$ in a deep, alpine lake environment. At the surface, at $42 \mathrm{~m}$ water depth, and in the water layer immediately above the sediment, AOA generally outnumbered AOB. However, in the surface water during summer stratification, when both AO were low in abundance, AOB were more numerous than AOA. Temporal distribution patterns of AOA and AOB were comparable. Higher abundances of amoA gene transcripts were observed at the onset and end of summer stratification. In summer, archaeal amoA genes and transcripts correlated negatively with temperature and conductivity. Concentrations of ammonium and oxygen did not vary enough to explain the amo $\mathrm{A}$ gene and transcript dynamics. The observed herbivorous zooplankton may have caused a hidden flux of mineralized ammonium and a change in abundance of genes and transcripts. At the surface, $\mathrm{AO}$ might have been repressed during summer stratification due to nutrient limitation caused by active phytoplankton.

\section{Introduction}

Nitrogen cycling is one of the major biogeochemical processes on Earth. The discovery of novel nitrogen-converting pathways in the past decades [1] has shown the lack of knowledge we had and still have on global nitrogen cycling. Additionally, intensified use of fertilizers and nitrogenous precipitation derived from industry and traffic has led to large changes in the $\mathrm{N}$-cycle in many ecosystems [2]. A major recent discovery in relation to the nitrification process was the role of Archaea in ammonia oxidation [3-5]. This notion has led to a great interest in the presence of ammoniaoxidizing archaea and bacteria in many ecosystems, often determined by the occurrence of archaeal and bacterial amo $A$ genes (e.g., $[6,7])$. In most analyses, the presence of archaeal amoA genes outnumbered those of bacteria by orders of magnitudes. What this means for the relative activities of both groups has only been investigated in a few environmental studies $[8,9]$.

The ecological importance of $\mathrm{AOA}$ and $\mathrm{AOB}$ has been determined in several studies; the relative abundance of $\mathrm{AOA}$ and $\mathrm{AOB}$ in soils is thought to be influenced mainly 
by $\mathrm{pH}[10,11]$, temperature [12], and ammonium $[13,14]$, while in marine systems, next to ammonium [15], oxygen concentrations are expected to play a major role in the presence and abundance of AOA and $\mathrm{AOB}[16,17]$. However, studies comprising this type of analyses in relation to the occurrence of $\mathrm{AOA}$ and $\mathrm{AOB}$ in freshwater systems lag behind those related to terrestrial and marine studies.

The ecology of nitrifying bacteria in lakes is well described throughout the years (e.g., [18-21]), but the mutual presence of $\mathrm{AOA}$ and $\mathrm{AOB}$ was recorded only in some lakes and only at one time point. Lehours et al. [22, 23] found a different archaeal and bacterial community in oxic and permanent anoxic parts of monomictic Lake Pavin. In the sediment of the hypertrophic Lake Taihu, archaea dominated the prokaryotic community, likely due to the low oxygen conditions; no archaea could be detected in the water column [24-26]. In high-altitude Tibetan lakes, salinity influenced the abundance and community composition of AOA, which outnumbered AOB [27].

A first freshwater interannual analysis of Archaea showed the presence of a high diversity of thaumarchaeota (formerly thought to be part of the crenarchaeota phylum) in sulfurous karstic Lake Vilar, but only on the basis of the presence of the 16S rRNA gene [28]. These authors observed differences in richness distribution and seasonality, but no clear correlations were obtained when multivariate statistical analyses were carried out. No temporal comparison of both AOA and $\mathrm{AOB}$ in freshwater ecosystems has been made to date.

Here we present a temporal and spatial study of the abundance of the amoA genes and the amo $A$ gene transcripts as indicators of the presence and the status of activity, respectively, of $\mathrm{AOB}$ and $\mathrm{AOA}$ in the oligomictic Lake Lucerne. This lake, with high thaumarchaeota-specific crenarchaeol concentrations [29] and relatively high amounts of nitrogen [30], was expected to present a good site for studying the ecology of ammonia oxidizers (AO). The AOA and $\mathrm{AOB}$ have a similar temporal distribution pattern, though the AOA outnumber the $\mathrm{AOB}$ gene abundance at $42 \mathrm{~m}$ water depth and water just above the sediment. In the surface water the $\mathrm{AO}$ gene numbers were lower in the summer months, at which time the $\mathrm{AOB}$ outnumber the $\mathrm{AOA}$, and a negative correlation of AOA with temperature and conductivity is found.

\section{Materials and Methods}

2.1. Location Description. Lake Lucerne is a perialpine lake located in Central Switzerland $\left(47^{\circ} \mathrm{N}, 8^{\circ} \mathrm{E}\right.$; $434 \mathrm{~m}$ a.s.l) at the northern alpine front, with a catchment area of $2124 \mathrm{~km}^{2}$. It covers an area of $116 \mathrm{~km}^{2}$, contains seven basins, and is fed by four major alpine rivers (Reuss, Muota, Engelberger $\mathrm{Aa}$, and Sarner Aa providing $~ 80 \%$ of the lakes total water supply $\left(109 \mathrm{~m}^{3} / \mathrm{s}\right)$ ) [31] with a 3.4-year residence time. As an oligomictic lake, a complete overturn occurs on average every six years. Sampling was done in the Kreuztrichter basin, one of the subbasins of Lake Lucerne, situated in the relatively open, western part of the lake.
2.2. Determination of Environmental Factors. Conductivity, temperature, oxygen, and $\mathrm{pH}$ were measured at the sampling location throughout the water column with a CTD scanner.

The concentrations of ammonium, nitrate, and dissolved organic nitrogen (DON) were measured on a SEAL-QuAAtro autoanalyzer (Seal, Norderstedt, Germany). Detection limits were $0.16 \mu \mathrm{mol}$ for ammonium, $0.10 \mu \mathrm{mol}$ for nitrate, and $2 \mu \mathrm{mol}$ for DON. The concentration of dissolved organic carbon (DOC) was determined with a Formacs DOC analyzer (Skalar, Breda, The Netherlands) with a detection limit of $20 \mu \mathrm{mol}$.

2.3. Sampling. Lake water was collected and filtered from the water surface ( $\mathrm{t}=\mathrm{top}, 0 \mathrm{~m}$ depth), the middle of the water column ( $\mathrm{m}=$ middle, $42 \mathrm{~m}$ depth), and at the bottom, just above the sediment $(b=$ bottom, varying from $72 \mathrm{~m}$ to $101 \mathrm{~m}$ depth due to slight location changes at different sampling times and the bathymetry at the sampling point in the Kreuztrichter basin) from January 2008 to April 2009. One sample was taken at each depth every month. Depending on the load of suspended particles, 1 to 3 liters of lake water were filtered. Samples for RNA analysis were frozen in a transportable liquid nitrogen freezer directly after filtration and stored at $-80^{\circ} \mathrm{C}$.

2.4. Nucleic Acids Extractions. DNA was extracted as described previously [32]. In brief, cells were lysed by bead-beating followed by a phenol-cholorform-isoamyl alcohol extraction. The DNA was precipitated and dissolved in $100 \mathrm{~mL}$ of molecular biology grade water (Sigma-Aldrich, St. Louis, MO, USA). After extraction, the DNA was purified on a Wizard column (Promega, Madison, WI, USA) and the quantity of DNA was determined spectrophotometrically using a Nanodrop ND-1000 spectrophotometer (Nanodrop Technology, Wilmington, DE, USA).

RNA was extracted with an adjusted protocol of Culley et al. [33], in which one $\mathrm{mL}$ of Trizol was added to a tube containing half of a $47 \mathrm{~mm} 0.2 \mu \mathrm{m}$ pore-size membrane filter, over which a known amount of water was filtered (1.5 to 2 liters depending on the amount of suspended material) and followed by subsequent bead-beating and RNA isolation steps. RNA was purified from DNA using the Ambion Turbo DNA-free kit (Applied Biosystems, Austin, TX, USA) twice on each sample (as described by the manufacturer). DNA contamination was tested by performing PCR on the samples with primer sets F357 and R518 [34] for the 16S rRNA gene of bacteria.

The BioRad iScript kit with random hexamers (Bio-Rad Laboratories Inc., Hercules, CA, USA) was used to perform reverse transcriptase cDNA production.

2.5. Plankton Measurements. Abundances of planktonic organisms were determined by microscopy in a monthly monitor of a mixed sample of the upper $20 \mathrm{~m}$ of the Kreuztrichter basin and were kindly provided for this study by Dr. Hans-Rudolf Bürgi (Eawag).

A principal component analysis on the presence of phytoand zooplankton was made, in which the explanatory power 

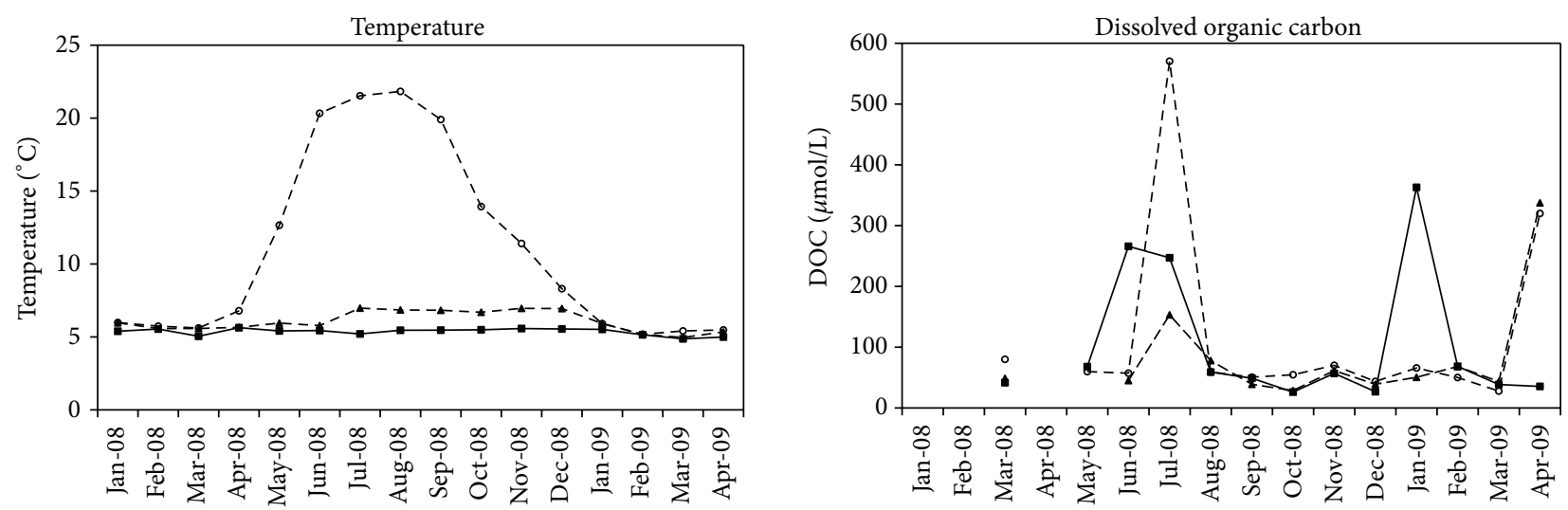

\section{$\rightarrow-$ Top $\rightarrow$ Bottom}
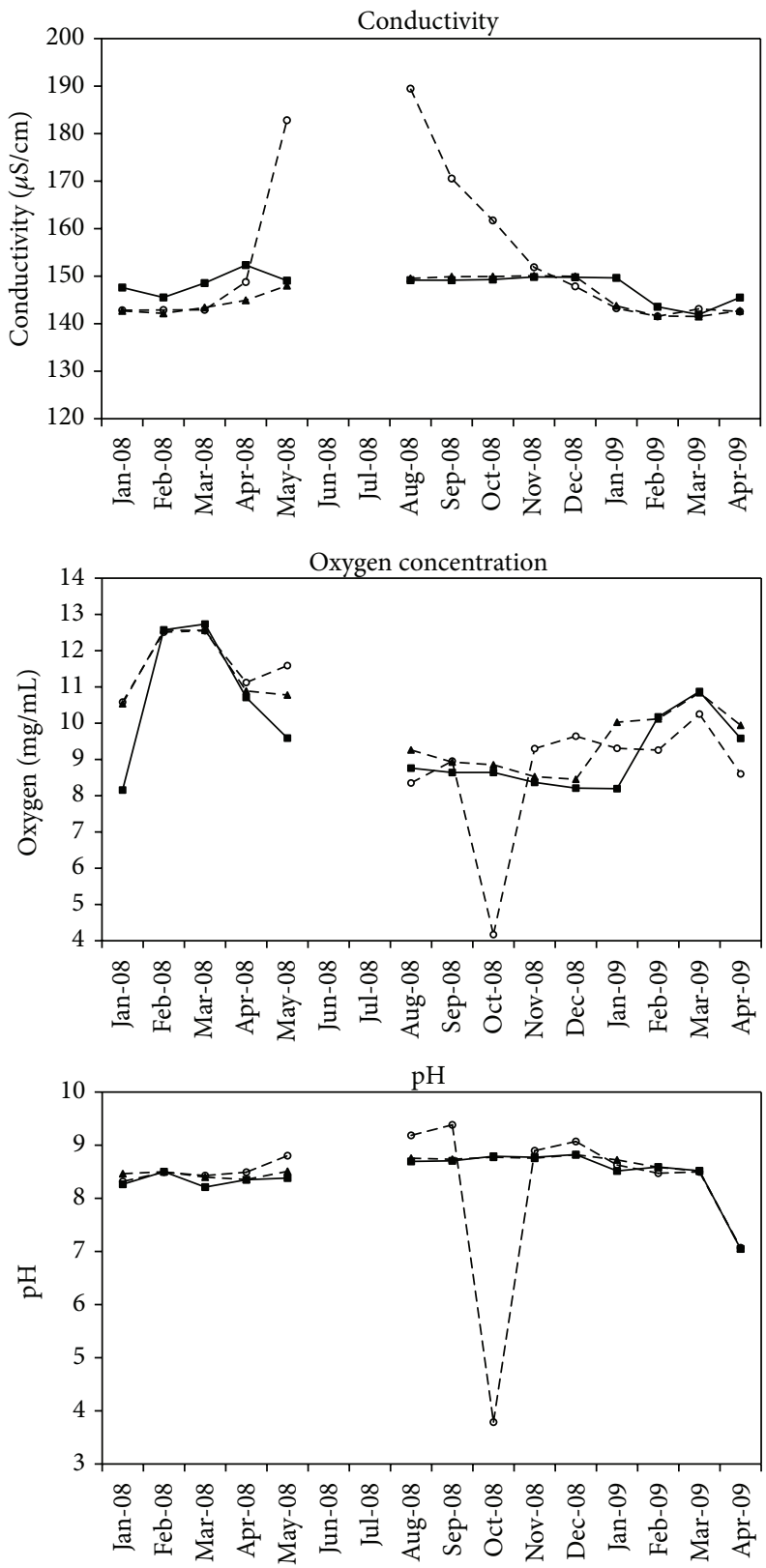
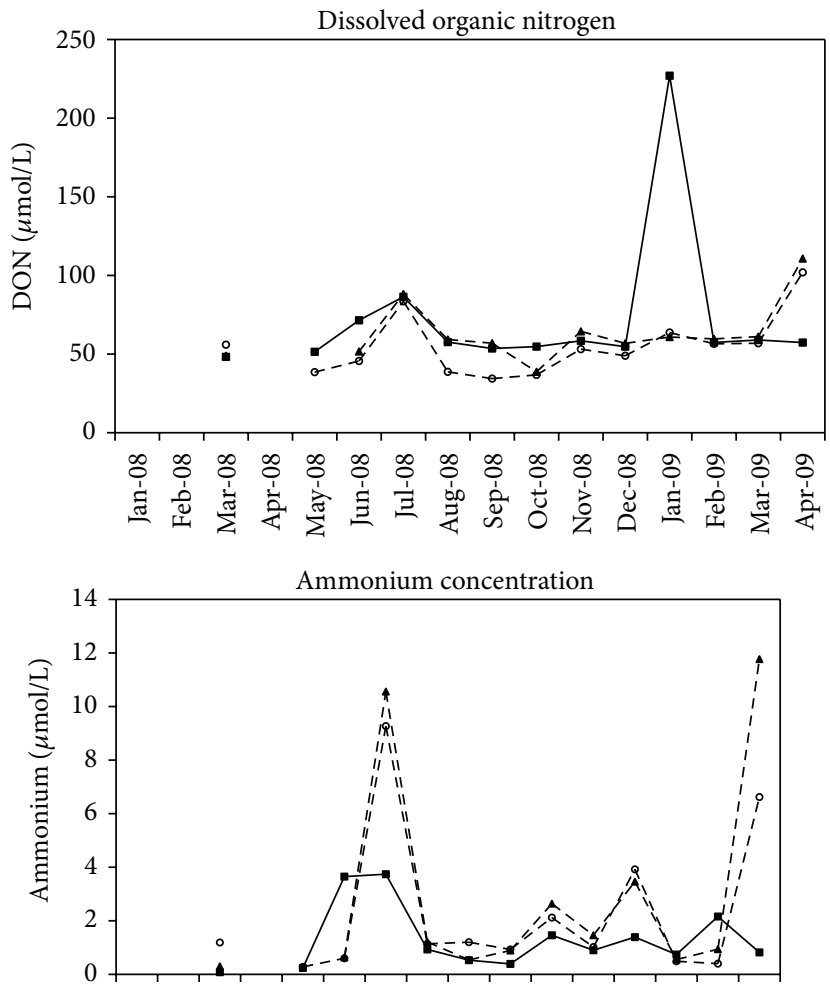

$\infty \infty^{\infty} \infty \infty^{\infty} \infty \infty^{\prime} \infty \infty^{\prime} \infty \infty^{\prime} \infty$ o o o

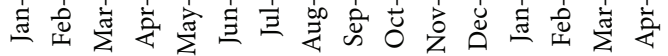

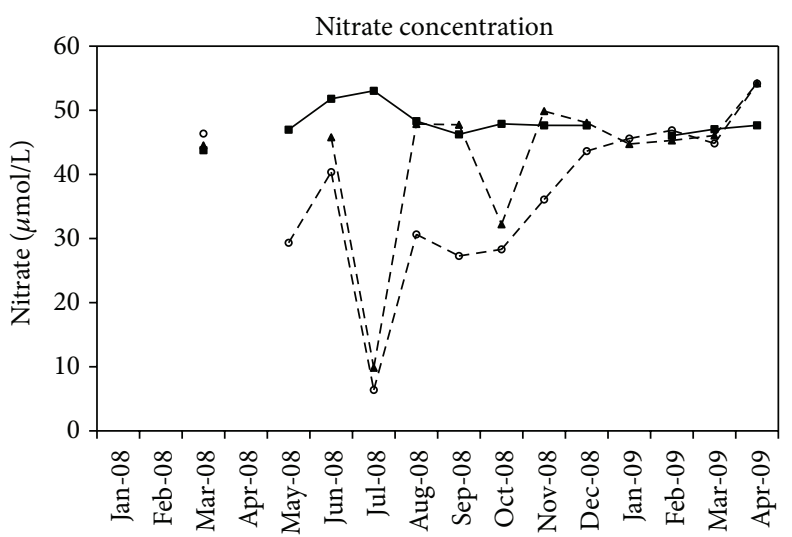



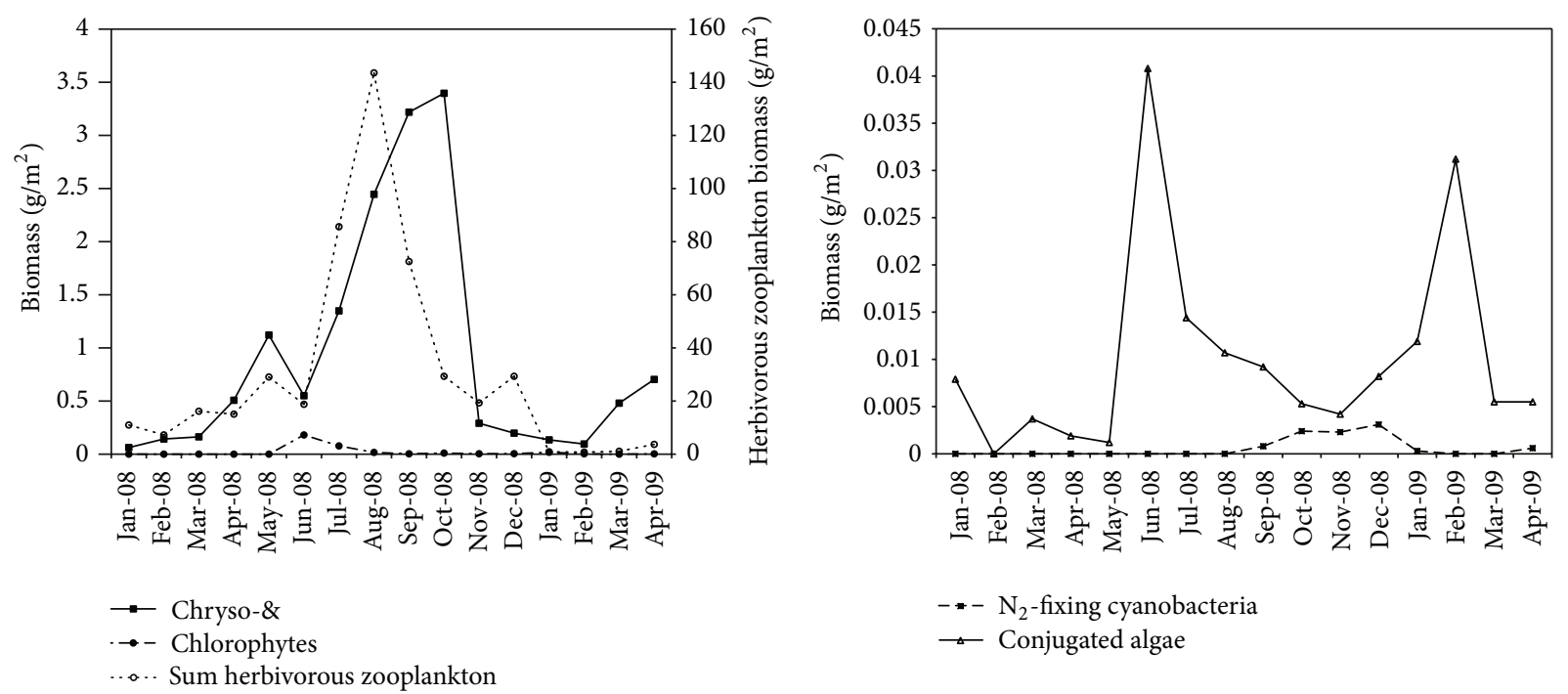

Figure 1: Temporal distribution of environmental factors at three water depths in Lake Lucerne. The single drop in pH and oxygen concentration in the surface water in October 2008 is expected to be caused by a failure of the equipment as such low $\mathrm{pH}$ values and oxygen concentrations are not observed in Lake Lucerne.

of the abundance of these organisms on the AOA and $\mathrm{AOB}$ amoA gene abundances and diversities was established.

2.6. Clone Library Construction and Sequencing. Clone libraries of archaeal amoA genes were made of the water samples taken in December by the use of the pGEM-T Vector system (Promega, Madison, WI, USA). Hundred clones were processed and analyzed per water depth. Selected clones were sequenced with their amplification primers (Macrogen Inc., Republic of Korea) (Supplementary Table 2 of the Supplementary Material available online at http://dx.doi .org/10.1155/2013/289478).

2.7. Quantitative PCR of Archaeal and Bacterial amoA Genes. qPCR of archaeal and bacterial $a m o A$ genes was performed in a $20 \mu \mathrm{L}$ mixture of $10 \mu \mathrm{L}$ iQTM SYBR Green Supermix (Bio$\mathrm{Rad}), 1 \mu \mathrm{M}$ of forward and reverse primers, and $0.2 \mathrm{mg} \mathrm{mL}-1$ BSA. For archaeal standards, serial dilutions of the linearized soil fosmid clone $54 \mathrm{~d} 9$ were used. For bacterial standards, a serial dilution of the linearized plasmid (pCR4-TOPO, Invitrogen) containing the amoA gene of Nitrosomonas europaea was used. For the archaeal $a m o A$ gene the forward primer $104(\mathrm{~L}) \mathrm{F}\left(5^{\prime}\right.$-GCAGGWGAYTACATYTTCTA- $\left.3^{\prime}\right)$ was designed after the alignment of soil, marine, and freshwater clone sequences [14] and modified including and favoring clone sequences obtained from archaeal amoA genes found in Lake Lucerne sampled in December 2008 (Supplementary Table 2). Thus, the primer should be considered specific for $a m o A$ gene sequences dominating this lake. Amplifications were performed in Realplex (Mastercycler ep realplex, Eppendorf). Melting curve analyses were performed at the end of every qPCR run to confirm the amplification of the target products only, followed by standard agarose gel electrophoresis for affirmation. The following qPCR-program was used for both analyses-initial denaturation: $95^{\circ} \mathrm{C}$ for 15 minutes followed by 40 cycles of $95^{\circ} \mathrm{C}$ for 15 seconds, $55^{\circ} \mathrm{C}$ for 30 seconds, and $72^{\circ} \mathrm{C}$ for 40 seconds.

2.8. Statistical Analysis. Statistical analysis was performed using the Statistica 9 program (Statsoft Inc., Tulsa, OK, USA). The gene abundance was log-transformed to create normal distributions. A table of Spearman rank-order correlations of all variables was subsequently produced. A multipleregression analysis and principal component analysis on the presence of phyto- and zooplankton and chemical compounds were made, in which the explanatory power of the concentrations of these compounds and organisms on the $\mathrm{AOA}$ and $\mathrm{AOB}$ amoA gene abundances and diversities was established.

\section{Results and Discussion}

3.1. Environmental Parameters. The oligotrophic nature of Lake Lucerne is reflected by an oxygenated water column with generally low nutrient levels, but with relatively high nitrogen concentrations in the form of nitrate (on average $63 \mu \mathrm{mol} / \mathrm{L}$ ) (Figure 1).

During our sixteen-month study, $\mathrm{pH}$ and oxygen did not vary at the different sampling depths of Lake Lucerne. More dynamic were the conductivity and temperature in the lake, especially in the surface water.

In July 2008 and April 2009, DOC and DON showed a peak at all depths, while in December 2008, DOC and DON peaked strongly in the water above the sediment, suggesting a more active decomposing microbial community at these times.

Ammonium concentrations were mostly around the detection level of $0.16 \mu \mathrm{M}$ but showed a peak in the surface 
TABLE 1: One-way ANOVA on the differences between the means of community characteristics of ammonia-oxidizing archaea and bacteria determined for summer and winter months, respectively. The difference is significant when $F_{\text {measured }}<F_{\text {critical }}$ and $F$ critical $=4.8443357$. Significant differences are shown in bold. Individual data have been presented by Vissers et al. (in press).

\begin{tabular}{|c|c|c|c|}
\hline Parameter & Water depth & $F_{\text {measured }}$ & $P$ \\
\hline \multirow{3}{*}{ Log archaeal 16S } & Surface & 5.048039 & 0.04615 \\
\hline & $-42 \mathrm{~m}$ & 0.118078 & 0.73761 \\
\hline & Above sediment & 0.708741 & 0.41779 \\
\hline \multirow{3}{*}{ Log archaeal $a m o A$} & Surface & 7.093356 & 0.02205 \\
\hline & $-42 \mathrm{~m}$ & 0.061664 & 0.82351 \\
\hline & Above sediment & 0.052174 & 0.41779 \\
\hline \multirow{3}{*}{ Log bacterial amoA } & Surface & 0.020078 & 0.88988 \\
\hline & $-42 \mathrm{~m}$ & 1.228674 & 0.29131 \\
\hline & Above sediment & 0.622908 & 0.44665 \\
\hline \multirow{3}{*}{ Number of archaeal 16S rRNA DGGE bands } & Surface & 2.678394 & 0.12998 \\
\hline & $-42 \mathrm{~m}$ & 0.206905 & 0.65805 \\
\hline & Above sediment & 0.151504 & 0.70453 \\
\hline \multirow{3}{*}{ Number of archaeal amoA DGGE bands } & Surface & 29.27228 & 0.00021 \\
\hline & $-42 \mathrm{~m}$ & 2.873572 & 0.11813 \\
\hline & Above sediment & 2.925275 & 0.11522 \\
\hline
\end{tabular}

water and at $42 \mathrm{~m}$ when nitrate showed a minimum. The opposing fluctuations of ammonium and nitrate concentrations may suggest that ammonia oxidation plays a role in Lake Lucerne, which is confirmed by low AOA and $\mathrm{AOB}$ abundances in the periods with high concentrations of ammonium and low concentrations of nitrate and vice versa (Figures 1 and 2).

3.2. $A O A$ and $A O B$ amoA Gene Numbers. The increase and decrease of $\mathrm{AOA}$ and $\mathrm{AOB}$ amoA gene abundances showed similar patterns among the sixteen monthly collected samples at all three depths, indicating that AOA and AOB are generally displaying similar population dynamics (Figure 2). This observation is supported by significant $(P<0.05)$ and positive Spearman rank-order correlations between the gene copy numbers (Supplementary Table 1).

An increase in abundance of both $\mathrm{AOA}$ and $\mathrm{AOB}$ was observed in March (surface) and April (deeper waters) 2008, with the onset of summer stratification in the water column of Lake Lucerne, and an increase in AO was again observed in December 2008 when the water layers mixed again. During the period of water stratification, the numbers of AOA at the surface declined more than those of AOB leading to a lower percentage of the total AO of the first one. This period of lower $\mathrm{AO}$ numbers and $\mathrm{AOB}$ dominance at the surface of the lake coincided with relatively warm water and a higher conductivity (Figure 1). When comparing the gene copy numbers obtained in the summer stratification period, that is, from June till September, for which ANOVA pointed to a different temperature compared with the rest of the sampling period, it appears that the means of the archaeal gene copy numbers obtained in these two periods were only significantly different in the surface water (Table 1). With bacterial gene copy numbers, no significant differences between the means were observed throughout the water column. Water depth did also not significantly affect the AOB $a m o A$ gene abundance in the water column of the lake. In contrast, the AOA amoA gene abundance increased from the surface to the deeper water layers, giving rise to an increasing $\mathrm{AOA} / \mathrm{AOB}$ ratio with depth, which is also observed in other aquatic systems [35-37].

We observed (Figure 2) and confirmed by one-way ANOVA that AOA in the surface water behaved differently from the AOA in the deeper waters $(P<0.005)$, which was not observed for $\mathrm{AOB}(P<0.6)$. This all suggests that the low $\mathrm{AOA} / \mathrm{AOB}$ ratio at the surface water is caused by an environment in which different AOA dynamics or even communities occur compared to waters at greater depth.

The most striking result of our temporal study was the generally similar behavior of the archaeal and bacterial ammonia-oxidizing communities through time, suggesting a situation in which $\mathrm{AOA}$ and $\mathrm{AOB}$ cooccur rather than compete for nutrients.

3.3. $A O A$ and $A O B$ amoA Gene Transcript Numbers. On the cDNA level, the differences between the two domains were even less pronounced (Figure 2, right panels). The transcripts of the amoA genes also showed mutual temporal dynamics and higher abundances in the water column at the onset and end of summer stratification, except in the middle of the water column, where the transcripts were most abundant during summer stratification. Higher gene transcript numbers at moments before and after stratification are likely due to mixing of the water column and subsequent increased nutrient availability leading to higher metabolic activities [38-40].

Generally, an increased amoA cDNA level was observed a month before or at the same time of a rise in $a m o A$ genes, suggesting a higher ammonia-oxidizing activity when cells started to multiply (Figure 2). This was, however, less clear for 

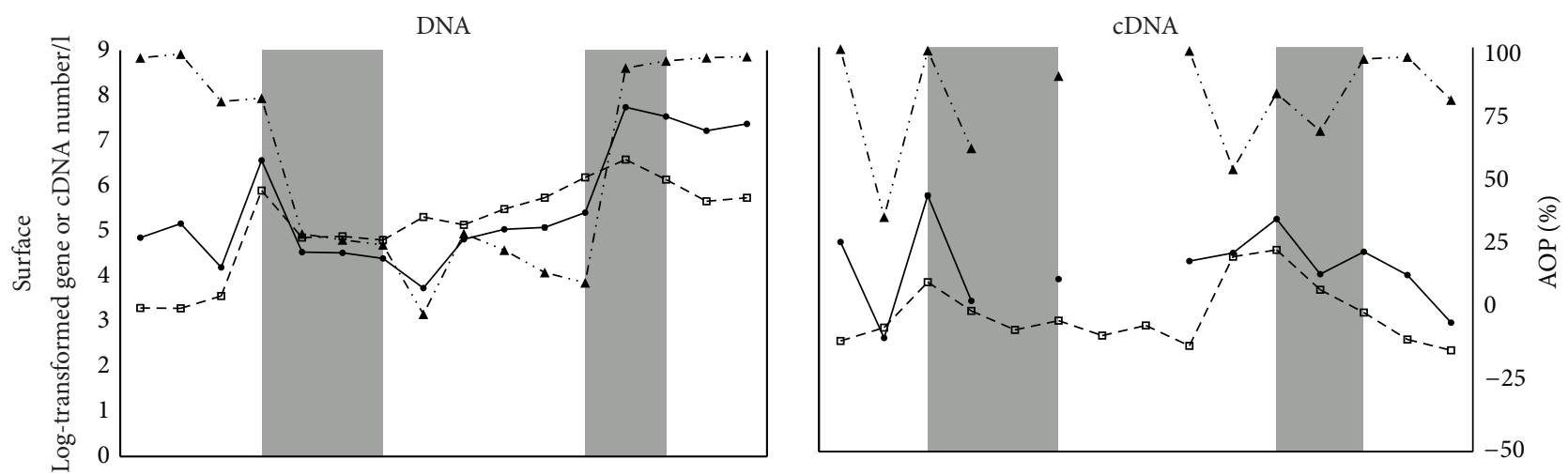

(a)
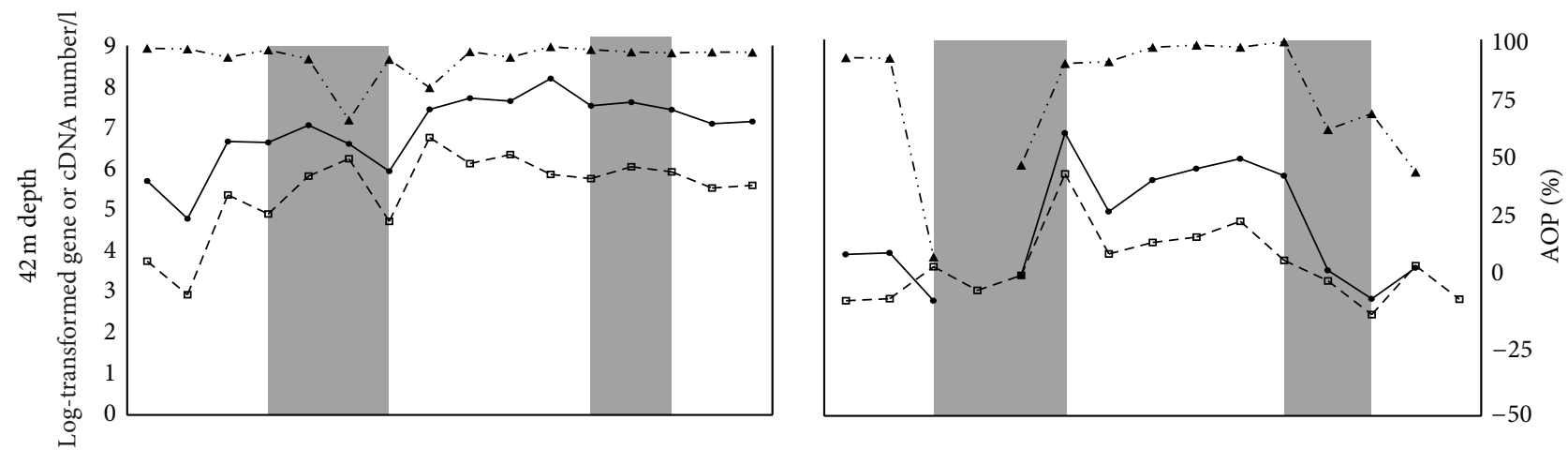

(b)
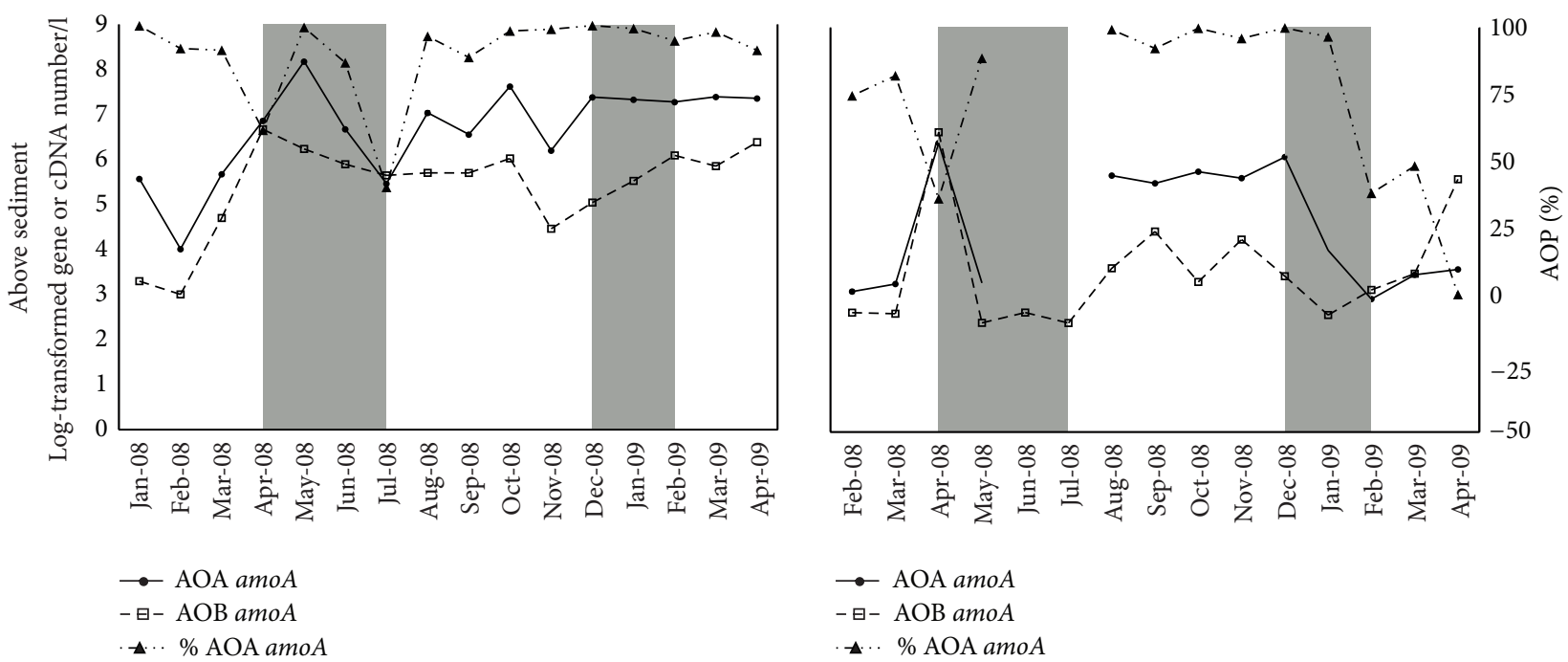

(c)

FIGURE 2: Temporal distribution of ammonia-oxidizing archaea (AOA) (solid lines, circles) and ammonia-oxidizing bacteria (AOB) (broken lines, squares), amoA gene abundances, and the archaeal percentage of the total amoA genes (broken line, triangles), all determined in three different layers in the water column of Lake Lucerne. In the left panels the DNA gene abundances are shown, on the right the cDNA abundances. Periods of mixing of the water layers are depicted by grey rectangles. Gene abundances were obtained by taking the average of three replicated qPCR analyses. Standard deviations of the replicates are indicated by error bars. 
the surface layer of the water column, where cDNA was even below the detection limit in the months in which the numbers of the amo $A$ gene of AOB exceeded those of the AOA. Hence, not only cell numbers of AOA were lower then, but also the transcription activity was undetectable for AOA. In the surface water in December 2008, however, when the AOA outnumbered the AOB once more, the amount of archaeal amoA-related cDNA had the highest increase rate, as one would expect at moments of population growth.

3.4. $A O A$ and $A O B$ amoA Genes and Transcripts in relation to Environmental Factors. Different environmental factors correlated to $\mathrm{AOA}$ and $\mathrm{AOB}$ amo $A$ genes and transcripts throughout seasons and depths, as is shown by Spearman rank-order correlation analysis (Supplementary Table 1) and supported and visualized by PCA analysis (Figure 3 ). The main environmental factors influencing the AOA populations in previous studies, that is, $\mathrm{pH}$, ammonium concentration, and oxygen availability, showed little dynamics in our study site; hence little influence on the AO gene and transcript abundances could be assigned to these factors. Additionally, the factors that showed the strongest explanatory power in our study, that is, temperature and conductivity, were constant throughout the season in the deeper water layers, opposite to the changes observed for the surface water. When considering all water depths of Lake Lucerne, conductivity explained $53 \%$ of the variance in the distribution of AOA. Conductivity was also of great influence on $\mathrm{AO}$ dispersal in Tibetan lakes [27], where lake biochemistry seemed to shape the archaeal community rather than historic events.

Conductivity in the Kreuztrichter basin was described to be affected by processes that are connected to phytoplankton dynamics, such as carbon assimilation, calcite precipitation, sedimentation, and decomposition in the hypolimnion [41]. A change in conductivity therefore may reflect a change in local nutrient availability due to phytoplankton activity, which probably affects the dynamics of AOA and AOB, though each in a specific manner as revealed by ANOVA (Table 1).

The concentration of ammonium, the expected substrate, was mostly around the detection limit and no relation with the transcript abundance of the functional gene for ammoniaoxidation could be found. The nitrate concentration in Lake Lucerne is expected to change by biochemical cycling only, as the inflow of fresh water is limited and originates from other basins of the Lake, rather than from the surrounding catchment. However, nitrate, the endproduct of nitrification, did not correlate with bacterial amo $A$ genes or gene transcript abundances neither with archaeal $a m o A$ transcripts. Nitrate did however correlate with archaeal $a m o A$ gene abundance, but only in the surface water. To date the comparisons of $\mathrm{AOA}$ and $\mathrm{AOB}$ ammonium uptake kinetics are based on a limited number of pure culture experiments, and so far it is unknown if $\mathrm{AOA}$ and $\mathrm{AOB}$ in natural environments behave similarly. AOA were found to thrive at low nutrient concentrations [42] and showed growth until ammonium concentrations fell below the detection level (i.e., $10 \mathrm{nM}$ ), which is a 100-fold lower than the threshold concentration for AOB $(1 \mu \mathrm{M}$ at near neutral $\mathrm{pH})$ [15]. In accordance with these findings, ammonium was generally around the detection limit in the waters of our study site, where AOB only reached low cell numbers (Figures 1 and 2) and were outnumbered by AOA by 1 or 2 orders of magnitude difference in gene abundance in the deeper waters. Also in the North Sea, a similar temporal dynamic of $\mathrm{AOA}$ and $\mathrm{AOB}$ was observed with AOA outnumbering $\mathrm{AOB}$ by 1 or 2 orders of magnitude [3], suggesting this might be more common in aquatic environments.

In the surface water the abundance of $\mathrm{AOB}$ was higher than that of AOA during summer stratification when temperature and conductivity increased (Figures 1 and 2); this is due to a negative correlation of AOA with conductivity and temperature, rather than a positive correlation of $\mathrm{AOB}$ with these factors. However, temperature and conductivity correlated positively with cDNA derived from archaeal and bacterial amoA in the deeper layers, although for the bacterial cDNA only at $42 \mathrm{~m}$ depth. Apparently, temperature and conductivity stimulated the transcription activity of the ammonia oxidizers in the deeper layers, but not in the surface water. Hence, some other factor must have been responsible for the relative increase of $\mathrm{AOB}$ in relation to $\mathrm{AOA}$ in the surface layer during summer stratification.

It has been suggested that oxygen influences the composition of $\mathrm{AOB}$ communities [43] and low oxygen levels may offer a niche for AOA $[16,17,44-46]$. However, since the concentration of oxygen varied only little at the different water depths of the well-oxygenated water column of Lake Lucerne, oxygen is not likely to be a selective environmental factor with respect to the presence of $\mathrm{AOA}$ and $\mathrm{AOB}$ in lake Lucerne.

3.5. Correlation of AO Genes and Gene Transcript Numbers to the Presence of Other Plankton. AOA amoA genes and gene transcripts in deeper waters, as well as AOB amoA transcripts throughout the water column, correlated to numbers of herbivorous zooplankton and $\mathrm{N}_{2}$-fixing cyanobacteria (Figure 4). These plankton groups may supply AOA and AOB directly or indirectly with extra ammonium from mineralization of organic nitrogen compounds. Correlations with herbivorous and mixotrophic zooplankton were found in all water depths. A possible explanation for increasing amounts of $a m o A$ transcripts might be the increase of activity during grazing. It has been shown in ammonia-limited chemostats containing pure cultures of $\mathrm{AOB}$ and heterotrophic bacteria that grazing by a flagellate lowered the number of ammoniaoxidizing cells present in the culture, but increased at the same time the oxidation rate per cell [47]. AOB cells have a higher amount of mRNA ready for ammonia oxidation at moments before growth is observed, which possibly causes the $\mathrm{AOB}$ population to recover faster after predation, while the AOA population needs more time to recover from phagotrophy.

In the surface water, a negative correlation was observed between AOA gene and gene transcript numbers on one side, and the numbers of conjugate algae and chrysophytes on the 

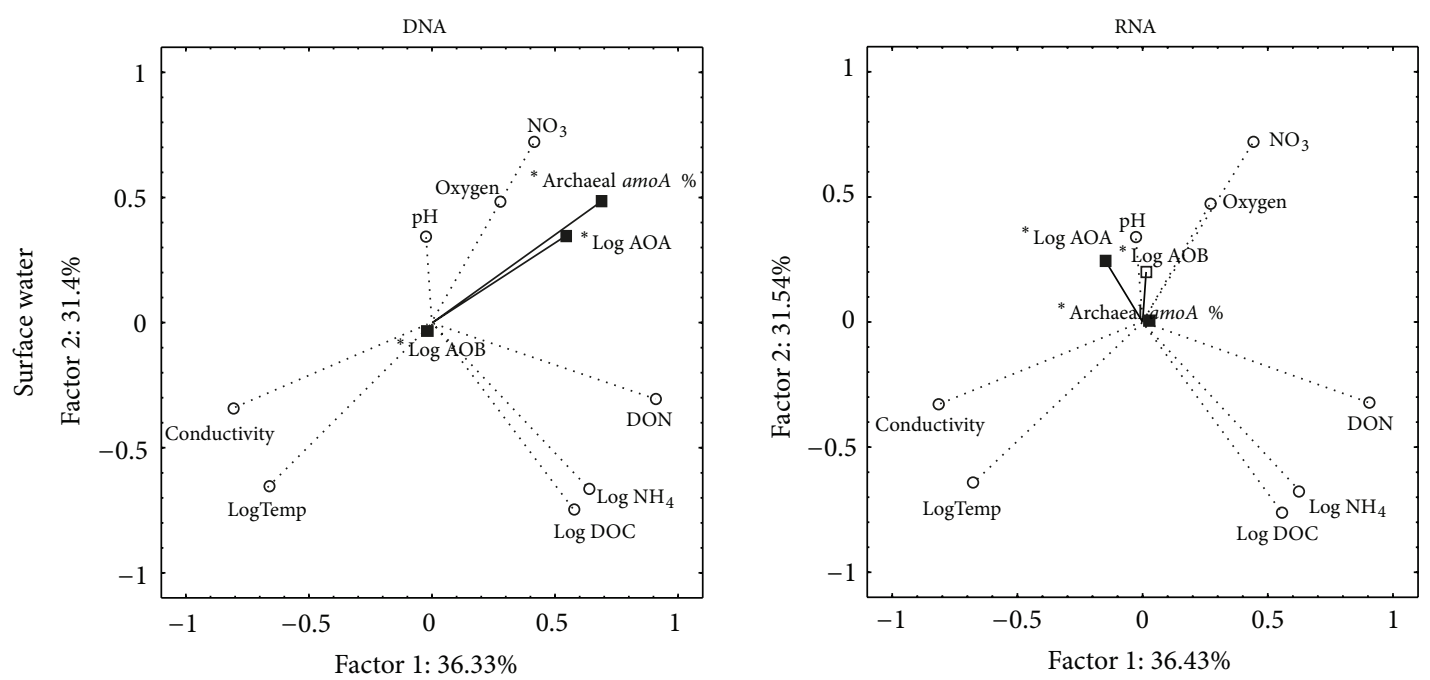

(a)
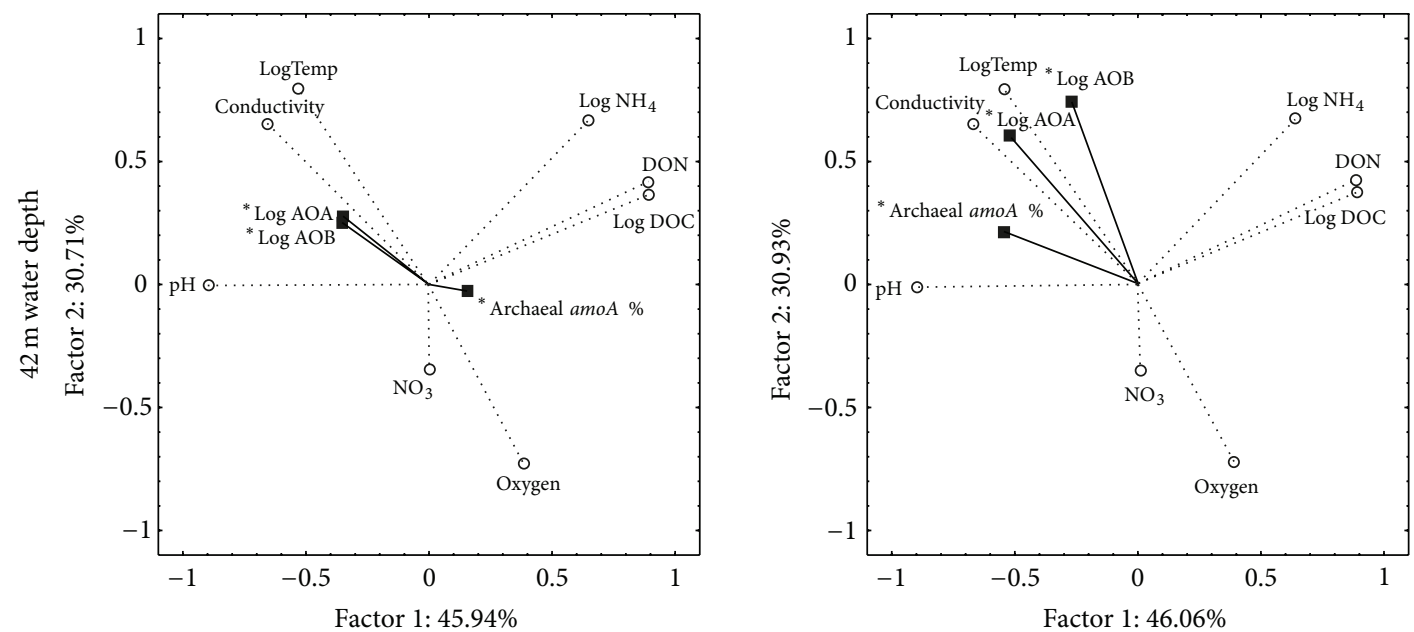

(b)
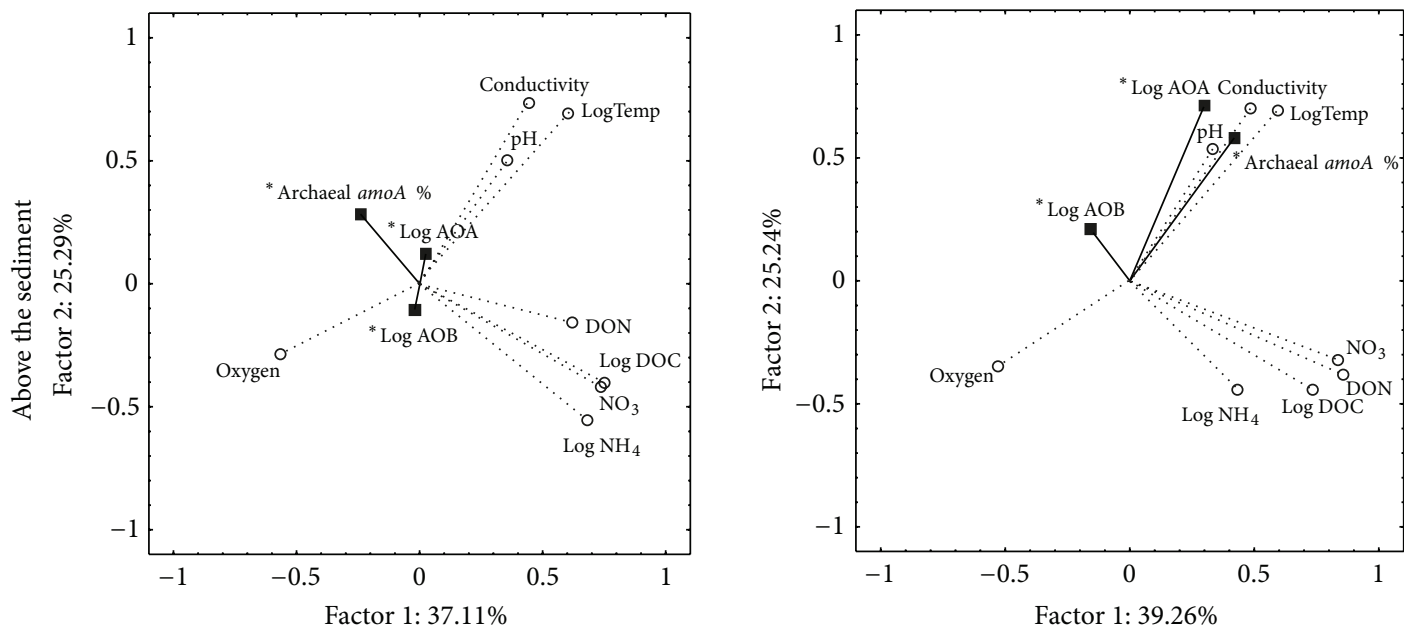

(c)

FIGURE 3: Principal component analysis of ammonia oxidizers DNA (left) and RNA (right) and environmental factors and nutrients in the surface water (above), $42 \mathrm{~m}$ water depth (middle), and water just above the sediment (below). A principal component analysis on chemical compounds was made, in which the explanatory power of the concentrations of these compounds on the AOA and AOB amoA gene abundances and diversities was established. Statistical analysis was performed using the Statistica 9 program (Statsoft Inc., Tulsa, OK, USA). 


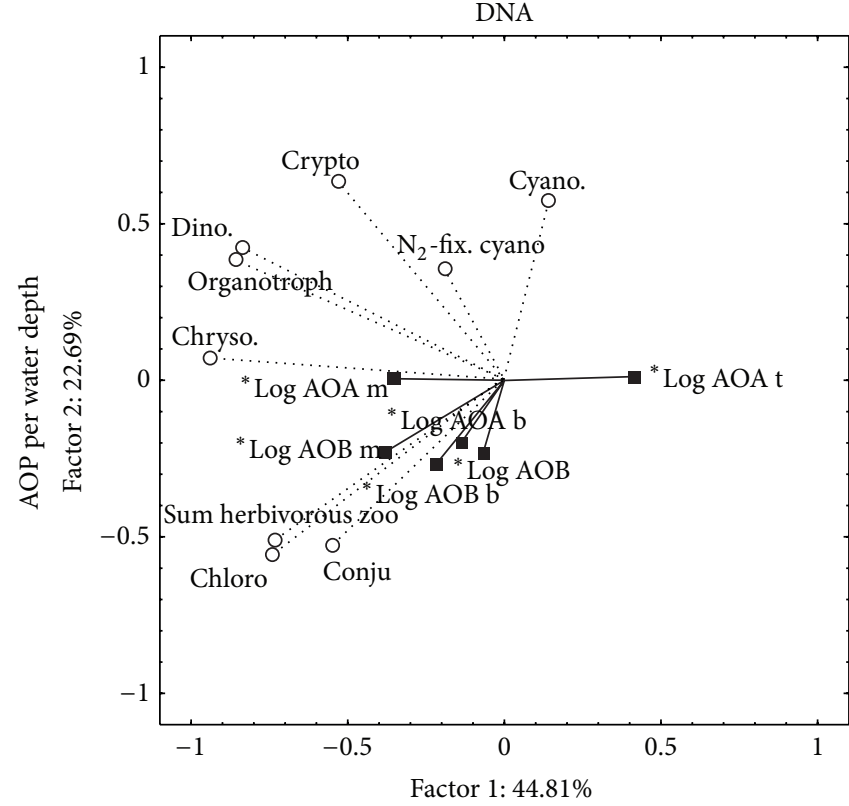

(a)

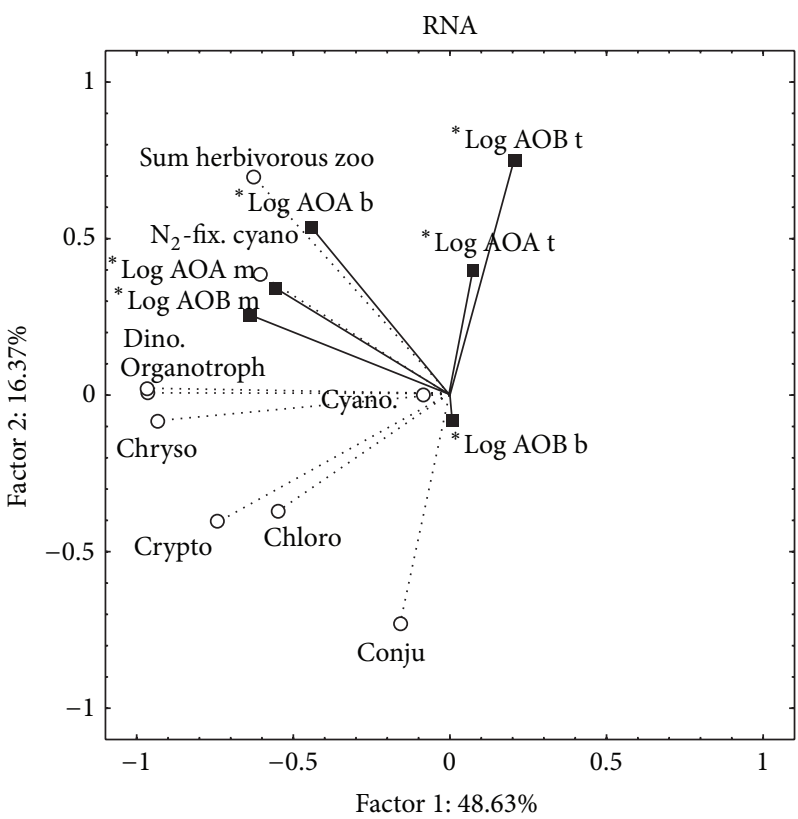

(b)

FIGURE 4: Principal component analysis of ammonia oxidizers DNA (a) and RNA (b) and other planktonic microorganisms abundance in the Kreuztrichter basin, Lake Lucerne. Ammonia oxidizers' abundances are printed per water depth on the representation of the abundance of the other planktonic organisms observed throughout the upper $20 \mathrm{~m}$ of the water column.

other side. Chrysophytes are described to be mixotrophs as they obtain energy either from light or by feeding on decaying or living cells [48]. This predation could cause the decline of the archaeal and bacterial cell numbers in the surface water during summer stratification, when the chrysophyte bloom was observed.

An explanation for the lower numbers of $\mathrm{AO}$ in the surface water may be found in surface-related factors such as a competition with phototrophic microorganisms for nutrients and $\mathrm{CO}_{2}$ or an inhibition by light. The community of $\mathrm{AOB}$ in the surface water is apparently less affected than the AOA by these factors from May till December 2008. Outside this period of summer stratification the negative factors for the AOA in the surface layer seem to be less severe, which might lead again to their dominance. More research is required to elucidate this differential effect of surface water factors on AOA and AOB.

\section{Conclusions}

The low availability of ammonium in the lake throughout the year may favor AOA over AOB leading to larger population sizes of the first group [49]. Although with different amplitudes, AOA and AOB followed more or less the same temporal changes throughout the water column. Assuming that they have to compete for the same resource, a similarity in community dynamics between archaeal and bacterial ammonia-oxidizing microorganisms is not expected. Even chaotic behavior of pelagic populations makes such a similarity in temporal dynamics not likely [50]. This either means that the amount of ammonium was not limiting or that
AOA can utilize other resources next to ammonium, as has been suggested by [51]. Increase in gene and gene transcript abundance cooccurred with the mixing of the water column before and after summer stratification in the lake, which may indicate a rapid response to changing conditions such as ammonium availability. In Lake Lucerne, ammonium levels were mostly very low. However, ammonium could be available as a nutrient for $\mathrm{AOA}$ and $\mathrm{AOB}$ by direct local production, which was supported by the observation that $\mathrm{AOB}$ and $\mathrm{AOA}$ in the deeper waters correlated to herbivorous zooplankton, which make ammonium available by their grazing activity. In the surface water, UV inhibition as well as predation and competition for nutrients and $\mathrm{CO}_{2}$ by zooplankton may have influenced the population size of the AOP negatively. In addition, not only the size of the AOA community based on both the abundance of the amoA gene and that of the 16S rRNA gene was significantly affected in the surface layer by factors prevailing during the period of summer stratification, but also the diversity of the dominant strains as appearing from DGGE profiling of the amoA gene [52] was significantly affected in this period (Table 1).

\section{Conflict of Interests}

The authors do not have any conflict of interests with the content of the paper.

\section{Acknowledgments}

This is publication number DW-2013-1001 of the Darwin Center for Biogeosciences, which partially funded this paper. 
The authors thank Cornelia Blaga of Utrecht University, Alois Zwyssig, and Michael Schurter both of Eawag Kastanienbaum for their help during the extensive field campaign. Their gratitude is expressed to Eawag for sharing their planktonic data of the Chrueztrichter basin with them. Additional financial support for the field campaign was obtained from the Schure-Beijerinck Popping fund and Darwin Center for Biogeosciences, publication number 5409 of the Netherlands Institute of Ecology (NIOO-KNAW).

\section{References}

[1] M. S. M. Jetten, “The microbial nitrogen cycle," Environmental Microbiology, vol. 10, no. 11, pp. 2903-2909, 2008.

[2] N. Gruber and J. N. Galloway, "An Earth-system perspective of the global nitrogen cycle," Nature, vol. 451, no. 7176, pp. 293296, 2008.

[3] C. Wuchter, B. Abbas, M. J. L. Coolen et al., "Archaeal nitrification in the ocean," Proceedings of the National Academy of Sciences of the United States of America, vol. 103, pp. 12317-12322, 2006.

[4] M. Könneke, A. E. Bernhard, J. R. De La Torre, C. B. Walker, J. B. Waterbury, and D. A. Stahl, "Isolation of an autotrophic ammonia-oxidizing marine archaeon," Nature, vol. 437, no. 7058, pp. 543-546, 2005.

[5] A. H. Treusch, S. Leininger, A. Kietzin, S. C. Schuster, H. P. Klenk, and C. Schleper, "Novel genes for nitrite reductase and Amo-related proteins indicate a role of uncultivated mesophilic crenarchaeota in nitrogen cycling," Environmental Microbiology, vol. 7, no. 12, pp. 1985-1995, 2005.

[6] C. A. Francis, K. J. Roberts, J. M. Beman, A. E. Santoro, and B. B. Oakley, "Ubiquity and diversity of ammonia-oxidizing archaea in water columns and sediments of the ocean," Proceedings of the National Academy of Sciences of the United States of America, vol. 102, no. 41, pp. 14683-14688, 2005.

[7] J. H. Rotthauwe, K. P. Witzel, and W. Liesack, "The ammonia monooxygenase structural gene $a m o A$ as a functional marker: molecular fine-scale analysis of natural ammonia-oxidizing populations," Applied and Environmental Microbiology, vol. 63, no. 12, pp. 4704-4712, 1997.

[8] G. W. Nicol, S. Leininger, C. Schleper, and J. I. Prosser, "The influence of soil $\mathrm{pH}$ on the diversity, abundance and transcriptional activity of ammonia oxidizing archaea and bacteria," Environmental Microbiology, vol. 10, no. 11, pp. 2966-2978, 2008.

[9] H. J. Di, K. C. Cameron, J. P. Shen et al., "Nitrification driven by bacteria and not archaea in nitrogen-rich grassland soils," Nature Geoscience, vol. 2, no. 9, pp. 621-624, 2009.

[10] G. W. Nicol, G. Webster, L. A. Glover, and J. I. Prosser, "Differential response of archaeal and bacterial communities to nitrogen inputs and $\mathrm{pH}$ changes in upland pasture rhizosphere soil," Environmental Microbiology, vol. 6, no. 8, pp. 861-867, 2004.

[11] J.-Z. He, J.-P. Shen, L.-M. Zhang et al., "Quantitative analyses of the abundance and composition of ammonia-oxidizing bacteria and ammonia-oxidizing archaea of a Chinese upland red soil under long-term fertilization practices," Environmental Microbiology, vol. 9, no. 9, pp. 2364-2374, 2007.

[12] M. Tourna, T. E. Freitag, G. W. Nicol, and J. I. Prosser, "Growth, activity and temperature responses of ammoniaoxidizing archaea and bacteria in soil microcosms," Environmental Microbiology, vol. 10, no. 5, pp. 1357-1364, 2008.
[13] L. E. Lehtovirta-Morley, K. Stoecker, A. Vilcinskas, J. I. Prosser, and G. W. Nicol, "Cultivation of an obligate acidophilic ammonia oxidizer from a nitrifying acid soil," Proceedings of the National Academy of Sciences of the United States of America, vol. 108, pp. 15892-15897, 2011.

[14] M. Tourna, M. Stieglmeier, A. Spang et al., "Nitrososphaera viennensis, an ammonia oxidizing archaeon from soil," Proceedings of the National Academy of Sciences of the United States of America, vol. 108, no. 20, pp. 8420-8425, 2011.

[15] W. Martens-Habbena, P. M. Berube, H. Urakawa, J. R. De La Torre, and D. A. Stahl, "Ammonia oxidation kinetics determine niche separation of nitrifying Archaea and Bacteria," Nature, vol. 461, no. 7266, pp. 976-979, 2009.

[16] P. Lam, G. Lavik, M. M. Jensen et al., "Revising the nitrogen cycle in the Peruvian oxygen minimum zone," Proceedings of the National Academy of Sciences of the United States of America, vol. 106, no. 12, pp. 4752-4757, 2009.

[17] M. J. L. Coolen, B. Abbas, J. Van Bleijswijk et al., "Putative ammonia-oxidizing Crenarchaeota in suboxic waters of the Black Sea: a basin-wide ecological study using $16 \mathrm{~S}$ ribosomal and functional genes and membrane lipids," Environmental Microbiology, vol. 9, no. 4, pp. 1001-1016, 2007.

[18] H. J. Laanbroek and A. Bollmann, "Nitrification in inland water," in Nitrification, B. B. Ward, M. G. Klotz, and D. J. Arp, Eds., pp. 385-404, ASM Press, Washington, DC, USA, 2011.

[19] M. Coci, P. L. E. Bodelier, and H. J. Laanbroek, "Epiphyton as a niche for ammonia-oxidizing bacteria: detailed comparison with benthic and pelagic compartments in shallow freshwater lakes," Applied and Environmental Microbiology, vol. 74, no. 7, pp. 1963-1971, 2008.

[20] C. B. Whitby, J. R. Saunders, R. W. Pickup, and A. J. McCarthy, "A comparison of ammonia-oxidiser populations in eutrophic and oligotrophic basins of a large freshwater lake," Antonie van Leeuwenhoek, International Journal of General and Molecular Microbiology, vol. 79, no. 2, pp. 179-188, 2001.

[21] W. F. Vincent and M. T. Downes, "Nitrate accumulation in aerobic hypolimnia-relative importance of benthic and planktonic nitrifiers in an oligotrophic lake," Applied and Environmental Microbiology, vol. 42, pp. 565-573, 1981.

[22] A. C. Lehours, C. Bardot, A. Thenot, D. Debroas, and G. Fonty, "Anaerobic microbial communities in Lake Pavin, a unique meromictic lake in France," Applied and Environmental Microbiology, vol. 71, no. 11, pp. 7389-7400, 2005.

[23] A. C. Lehours, P. Evans, C. Bardot, K. Joblin, and F. Gérard, "Phylogenetic diversity of archaea and bacteria in the anoxic zone of a meromictic lake (Lake Pavin, France)," Applied and Environmental Microbiology, vol. 73, no. 6, pp. 2016-2019, 2007.

[24] L. Liu, Y. Peng, X. Zheng, L. Xiao, and L. Yang, "Vertical structure of bacterial and archaeal communities within the sediment of a eutrophic lake as revealed by culture-independent methods," Journal of Freshwater Ecology, vol. 25, no. 4, pp. 565573,2010 .

[25] Y. Wu, Y. Xiang, J. Wang, J. Zhong, J. He, and Q. L. Wu, "Heterogeneity of archaeal and bacterial ammonia-oxidizing communities in Lake Taihu, China," Environmental Microbiology Reports, vol. 2, no. 4, pp. 569-576, 2010.

[26] W. Ye, X. Liu, S. Lin et al., "The vertical distribution of bacterial and archaeal communities in the water and sediment of Lake Taihu," FEMS Microbiology Ecology, vol. 70, no. 2, pp. 263-276, 2009. 
[27] A. Hu, T. Yao, N. Jiao, Y. Liu, Z. Yang, and X. Liu, "Community structures of ammonia-oxidising archaea and bacteria in highaltitude lakes on the Tibetan Plateau," Freshwater Biology, vol. 55, no. 11, pp. 2375-2390, 2010.

[28] M. Llirós, E. O. Casamayor, and C. Borrego, "High archaeal richness in the water column of a freshwater sulfurous karstic lake along an interannual study," FEMS Microbiology Ecology, vol. 66, no. 2, pp. 331-342, 2008.

[29] C. I. Blaga, G. J. Reichart, O. Heiri, and J. S. Sinninghe Damsté, "Tetraether membrane lipid distributions in water-column particulate matter and sediments: a study of 47 European lakes along a north-south transect," Journal of Paleolimnology, vol. 41, no. 3, pp. 523-540, 2009.

[30] H. R. Bürgi and P. Stadelmann, "Alteration of phytoplankton structure in Lake Lucerne due to trophic conditions," Aquatic Ecosystem Health, vol. 5, pp. 45-49, 2002.

[31] M. Schnellmann, F. S. Anselmetti, D. Giardini, J. A. McKenzie, and S. N. Ward, "Prehistoric earthquake history revealed by lacustrine slump deposits," Geology, vol. 30, pp. 1131-1134, 2002.

[32] E. W. Vissers, P. L. E. Bodelier, G. Muyzer, and H. J. Laanbroek, "A nested PCR approach for improved recovery of archaeal 16S rRNA gene fragments from freshwater samples," FEMS Microbiology Letters, vol. 298, no. 2, pp. 193-198, 2009.

[33] D. E. Culley, W. P. Kovacik, F. J. Brockman, and W. Zhang, "Optimization of RNA isolation from the archaebacterium Methanosarcina barkeri and validation for oligonucleotide microarray analysis," Journal of Microbiological Methods, vol. 67, no. 1, pp. 36-43, 2006.

[34] G. Muyzer, E. C. De Waal, and A. G. Uitterlinden, "Profiling of complex microbial populations by denaturing gradient gel electrophoresis analysis of polymerase chain reaction-amplified genes coding for $16 \mathrm{~S}$ rRNA," Applied and Environmental Microbiology, vol. 59, no. 3, pp. 695-700, 1993.

[35] D. L. Kirchman, H. Elifantz, A. I. Dittel, R. R. Malmstrom, and M. T. Cottrell, "Standing stocks and activity of Archaea and Bacteria in the western Arctic Ocean," Limnology and Oceanography, vol. 52, no. 2, pp. 495-507, 2007.

[36] C. Callieri, G. Corno, E. Caravati, S. Rasconi, M. Contesini, and R. Bertoni, "Bacteria, Archaea, and Crenarchaeota in the epilimnion and hypolimnion of a deep holo-oligomictic lake," Applied and Environmental Microbiology, vol. 75, no. 22, pp. 7298-7300, 2009.

[37] C. Tamburini, M. Garel, B. Al Ali et al., "Distribution and activity of Bacteria and Archaea in the different water masses of the Tyrrhenian Sea," Deep-Sea Research Part II, vol. 56, no. 11-12, pp. 700-712, 2009.

[38] M. Winder, "Photosynthetic picoplankton dynamics in Lake Tahoe: temporal and spatial niche partitioning among prokaryotic and eukaryotic cells," Journal of Plankton Research, vol. 31, no. 11, pp. 1307-1320, 2009.

[39] R. Naiman, J. J. Magnuson, D. M. McKnight, and J. A. Stanford, The Freshwater Imperative: A Research Agenda, Island Press, Washington, DC, USA, 1995.

[40] S. Fietz, G. Kobanova, L. Izmesteva, and A. Nicklisch, "Regional, vertical and seasonal distribution of phytoplankton and photosynthetic pigments in Lake Baikal," Journal of Plankton Research, vol. 27, no. 8, pp. 793-810, 2005.

[41] H. Bührer and H. Ambühl, "Lake Lucerne, Switzerland, a long term study of 1961-1992," Aquatic Sciences, vol. 63, no. 4, pp. 432-456, 2001.

[42] T. H. Erguder, N. Boon, L. Wittebolle, M. Marzorati, and W. Verstraete, "Environmental factors shaping the ecological niches of ammonia-oxidizing archaea," FEMS Microbiology Reviews, vol. 33, no. 5, pp. 855-869, 2009.

[43] A. Bollmann and H. J. Laanbroek, "Influence of oxygen partial pressure and salinity on the community composition of ammonia-oxidizing bacteria in the Schelde estuary," Aquatic Microbial Ecology, vol. 28, no. 3, pp. 239-247, 2002.

[44] J. M. Beman, B. N. Popp, and C. A. Francis, "Molecular and biogeochemical evidence for ammonia oxidation by marine Crenarchaeota in the Gulf of California," ISME Journal, vol. 2, no. 4, pp. 429-453, 2008.

[45] P. Lam, M. M. Jensen, G. Lavik et al., "Linking crenarchaeal and bacterial nitrification to anammox in the Black Sea," Proceedings of the National Academy of Sciences of the United States of America, vol. 104, no. 17, pp. 7104-7109, 2007.

[46] J. Yan, S. C. M. Haaijer, H. J. M. Op den Camp et al., "Mimicking the oxygen minimum zones: stimulating interaction of aerobic archaeal and anaerobic bacterial ammonia oxidizers in a laboratory-scale model system," Environmental Microbiology, vol. 14, pp. 3146-3158, 2012.

[47] F. J. M. Verhagen and H. J. Laanbroek, "Competition for ammonium between nitrifying and heterotrophic bacteria in dual energy-limited chemostats," Applied and Environmental Microbiology, vol. 57, no. 11, pp. 3255-3263, 1991.

[48] D. A. Holen and M. E. Boraas, "Mixotrophy in chrysophytes," in Chrysophyte Algae Ecology, Phylogeny and Development, pp. 119-140, Cambridge University Press, 1995.

[49] C. Schleper and G. W. Nicol, "Ammonia-oxidising archaeaphysiology, ecology and evolution," in Advances in Microbial Physiology, vol. 57, pp. 1-41, Academic Press Ltd-Elsevier Science, London, UK, 2010.

[50] J. Huisman and F. J. Weissing, "Biodiversity of plankton by species oscillations and chaos," Nature, vol. 402, no. 6760, pp. 407-410, 1999.

[51] P. C. Blainey, A. C. Mosier, A. Potanina, C. A. Francis, and S. R. Quake, "Genome of a low-salinity ammonia-oxidizing archaeon determined by single-cell and metagenomic analysis," PLoS ONE, vol. 6, no. 2, Article ID e16626, 2011.

[52] E. W. Vissers, C. I. Blaga, P. L. E. Bodelier et al., "Seasonal and vertical distribution of putative ammonia-oxidizing thaumarchaeotal communities in an oligotrophic lake," FEMS Microbiology Ecology, vol. 83, pp. 515-526, 2013. 

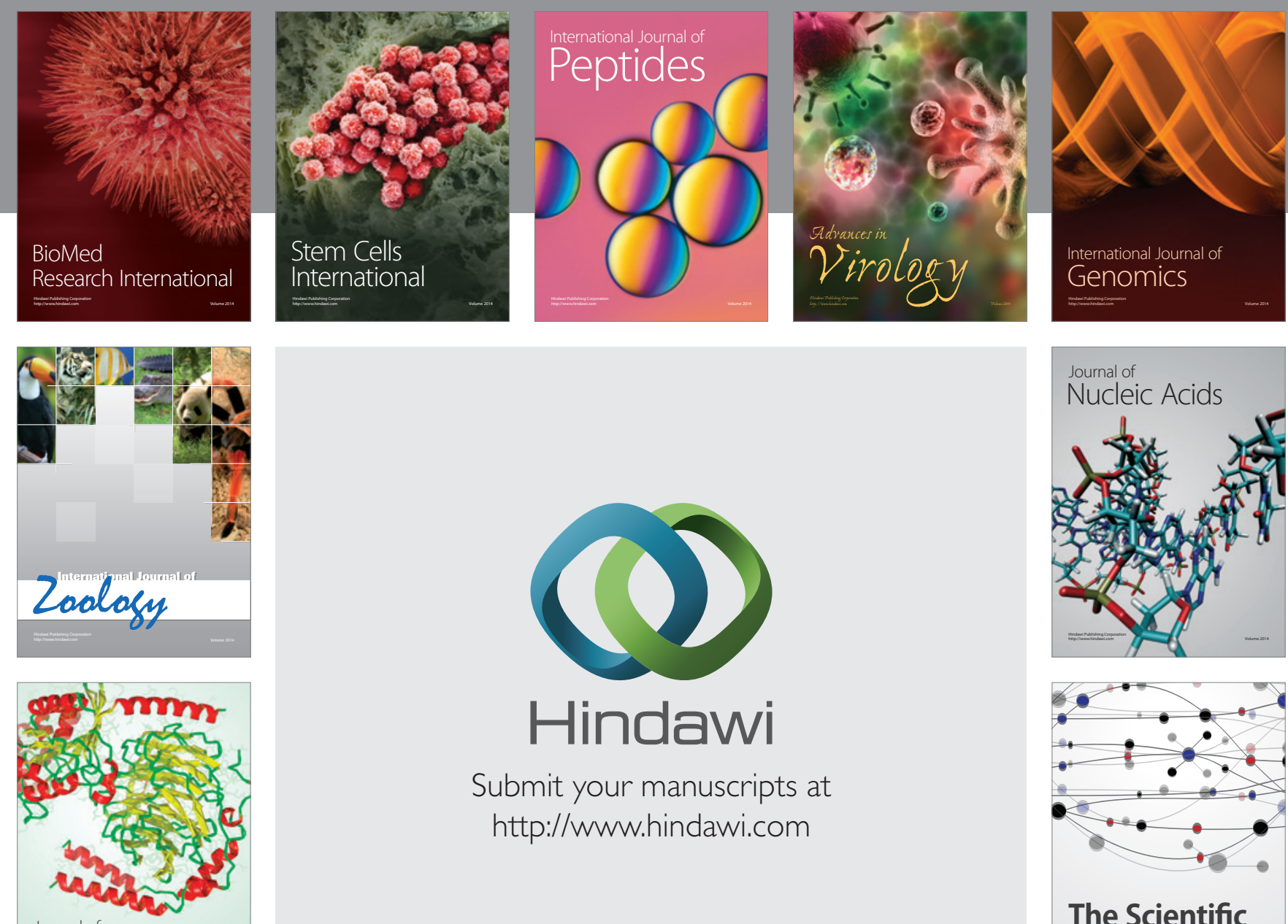

Submit your manuscripts at

http://www.hindawi.com

Journal of
Signal Transduction
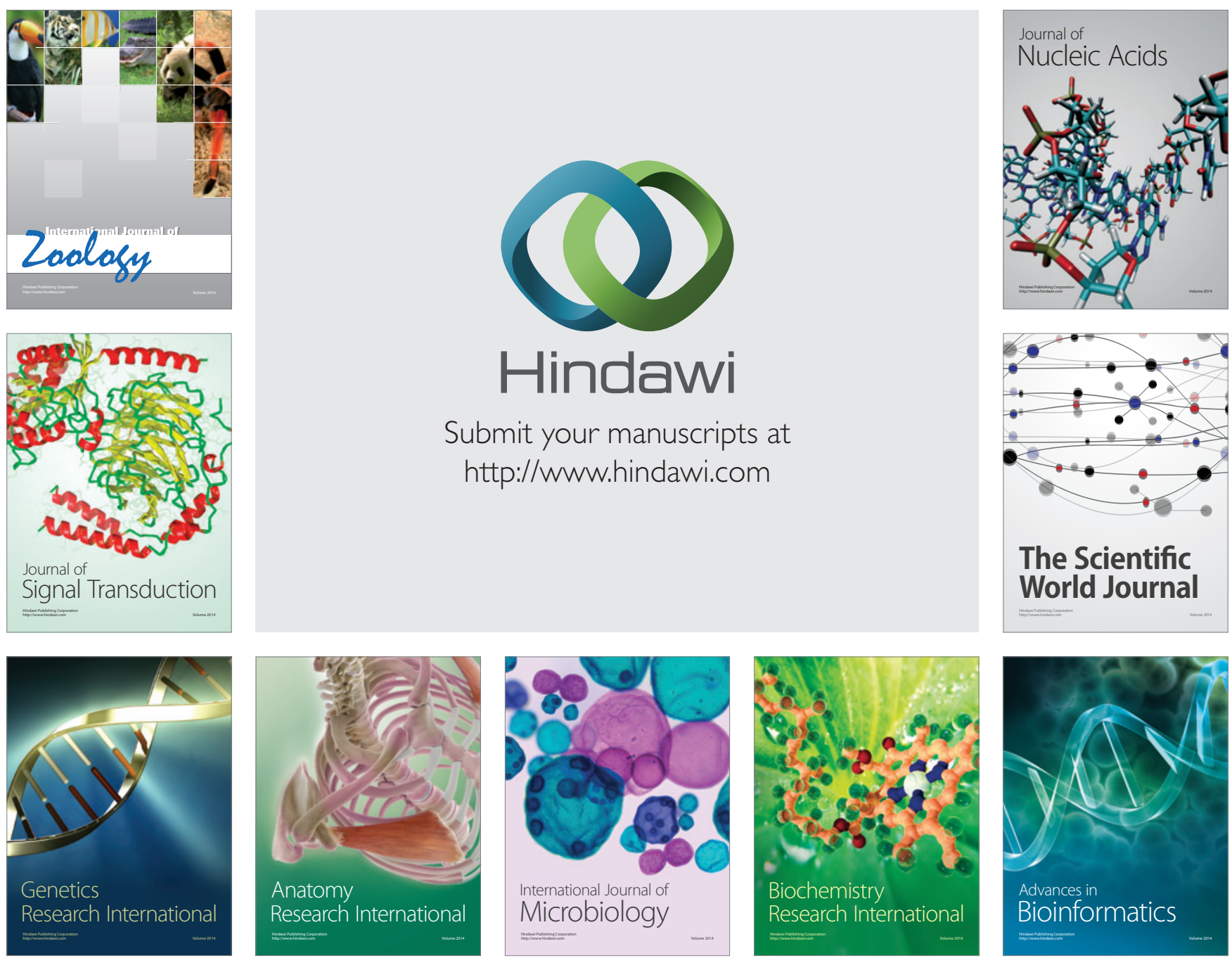

The Scientific World Journal
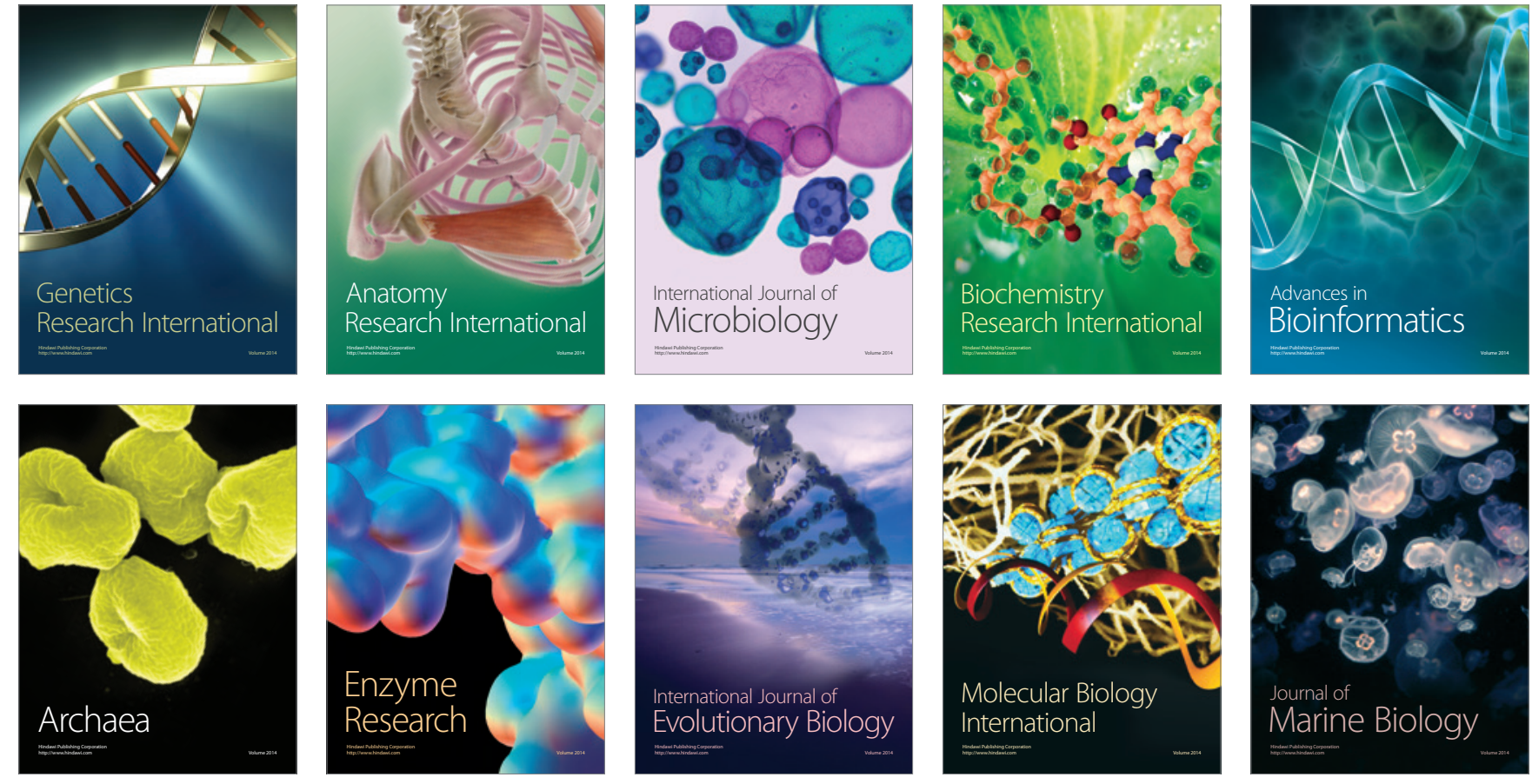